\title{
SEREN TAUN GURU BUMI HARMONY OF ISLAM AND PASUNDAN CULTURE
}

\author{
Abdurrahman Misno BP \\ College of Islamic Economics of Tazkia Bogor \\ drmisnomei@tazkia.ac.id
}

\begin{abstract}
The advent of Islam in Tatar Sunda (West Java) lent a new color to the culture that had previously existed there. The nature of Islam which was friendly to the local culture, made it easy to be accepted by the Sundanese people without bloodshed. The results are a variety of cultural rituals rooted in Sundanese culture yet rich with Islamic culture. Seren Taun Guru Bumi is one of the rituals of the Sundanese people deeply-rooted in the belief of Nyi Pohaci (Dewi Sri) as the goddess of fertility. The involvement of the researcher in this ritual made the data a primary source which is the implementation of Seren Taun Guru Bumi in Sindang Barang Cultural Village, Bogor, West Java. This research shows that the ritual of Seren Taun Guru Bumi is a form of Islamic harmony with the Sundanese culture. Islamic culture assimilates in the frame of Sundanese traditions in Tatar Sunda, in which both are brought together in the ritual as a form of gratitude to God Almighty.
\end{abstract}

Keywords: Seren Taun Guru Bumi, Acculturation, Sunda, Sindangbarang, Bogor

\section{BACKGROUND}

Humans as homo religion have the instinct that there are other forces outside them which manifests itself in various forms of belief in the power of gods and goddesses that can bring good or bad. This belief leads humans to feel the need to give an expression of gratitude and thanks for the good things they receive in this world. Humans also feel the need to make certain rituals to avoid the wrath of the gods. The belief in gods has spread across Indonesia, from the Anak Dalam tribe in Jambi to the Dani in Papua. It was present in various types of people, from coastal communities to the agricultural society, each having a variety of their respective beliefs. ${ }^{1}$

${ }^{1}$ Johan Iskandar and Budiawati S. Iskandar, Agroekosistem Orang Sunda, Bandung: Kiblat Utama, 2011, p. 46. 
One of the many beliefs that exist in the agrarian society in Indonesia is the goddess who is reagrded as the origin of rice. The goddess is believed to be the protector and maintainer of rice plant that becomes the staple food of an agrarian society. Known as Dewi Sri, she is a woman who became the goddess of the ruler and the goddess of fertility for rice plant. Dewi Sri in the Sunda agrarian society, according to research conducted by Hidding, is known as Nyi Sri Pohatji Sanghyang and often associated with the myth of the origin of the rice in West Java. ${ }^{2}$ This myth says that the rice plant was derived from the body Dewi Sri or Dewi Tisnawati that was buried. ${ }^{3}$

Belief in the goddess has resulted in the ritual of exaltation in the form of offerings and ceremonies. The Baduy, believed to be a native Sundanese people, are still practice the traditional way of the rice planting as a form of glorifying Nyi Pohaci. Starting from the beginning of the planting accompanied by angklung to harvest and storage in the leuit, all is carried out solemnly. ${ }^{4}$

Seren Taun Guru Bumi is one of the rituals performed by the agrarian society in Indonesia, especially in West Java. The ritual is still practiced today. Even in some places like in Kuningan and Bogor, it has become one of the cultural tourism which attracted many foreign and domestic tourists. Actually, the ritual practice is not only the exclusive Sundanese culture, but it also takes place in many other communities of Indonesia since this celebration is usually held by a series of ritual of sedekah bumi. ${ }^{5}$

The ritual of Seren Taun Guru Bumi continued to be practiced until Islam came and was embraced by the Pasundan society. Then there was another attempt to complete each other between Islam and Sundanese culture to create a harmony between Islam and Sundanese culture in the form of ritual ceremonies of the Seren Taun Guru Bumi. In the perspective of anthropology, this ritual can be categorized as a form of acculturation between the Sundanese culture and Islam, but on the negative side it can be regarded as a form of syncretism between Islam and Sunda. ${ }^{6}$

${ }^{2}$ Soepanto, “Asal Mula Padi (Tjerita Rakjat dari Pasundan)" in Kumpulan Tjerita Rakjat Indonesia, (Bandung: Urusan Adat-Istiadat dan Tjerita Rakjat Dep.P.D dan K Djawatan Kebudayaan, 1963), p. 22-25.

${ }^{3}$ Hariani Santikno, "Dewi Sri: Unsur Pemujaan Kesuburan pada Mitos Padi” in Majalah Ilmu-ilmu Sastra Indonesia. No. 13 AK PIA/1977, p. 53-67.

${ }^{4}$ Abdurrahman Misno, Reception Through Selection Modification: Antropologi Hukum Islam di Indonesia, Yogyakarta: Deepublih, 2016, p. 154.

${ }^{5}$ Edi S. Ekajati, Masyarakat Sunda dan Kebudayaannya (Jakarta: Giri Pasaka, 1984), p. 129.

${ }^{6}$ Irwan Abdullah, "Kraton, Upacara, dan Politik Simbol: Kosmologi dan Sinkretisme di Jawa”, in Humaniora, No. 1, Vo. 1, 1990, p. 87. Also read Parsudi Suparlan, "Kata Pengantar" in Mujahirin Thohir, Wacana Masyarakat dan Kebudayaan Jawa Pesisir (Semarang: Bendera, 1999), p. 25. Also read Mark R. Woodward, Islam in Java: Normative Piety and Mysticism in 
As a communal ritual, the practice Seren Taun Guru Bumi is a manifestation of belief and local culture. Since culture is a 'system' symbol which serves to direct the behavior of religious people, ${ }^{7}$ in the practice of Seren Taun Guru Bumi, religious texts are negotiated creatively to a give new meaning. As a consequence, the process of disposal or even deviation from religious texts is inevitable. ${ }^{8}$ This is evident from the origins of this tradition which is an attempt to glorify Dewi Sri that was derived from pagan beliefs, and when Islam came it was mixed with Islamic culture.

Based on the background of the problem, it can be seen that the currently practiced ritual ceremony of Seren Taun Guru Bumi is the result of harmony between Islam and Sundanese culture, then how exactly was the pocess of this harmony? Moreover, how exactly could this ritual become an integral part of Pasundan society? This article examines the procession of Seren Taun Guru Bumi in Cultural village of Sindang Barang, Bogor, West Java.

\section{SEREN TAUN GURU BUMI IN SUNDANESE PUBLIC DISCOURSE}

Seren Taun Guru Bumi is a ritual to glorify Nyi Pohaci as the goddess of rice among the Sundanese people. This ritual has been going very long since the formation of this tribe. It was also allegedly a tradition of the agrarian society in other regions such as India, Thailand, Champa and other Asian regions. The Seren Taun ritual is held at the cultural village of Singdang Barang is reimplemented after tens of years of inactivity. The cultural village of Singdang Barang itself is a settlement that is made as a miniature village of the past Sundanese culture. According to Abah Ukat, an elder in the cultural village of Sindang Barang, Seren Taun Guru Bumi is an attempt to ngamumule (preserve) the Sundanese culture, especially in Bogor that has already started to disappear. ${ }^{9}$

The best time to carry out the Seren Taun ceremony is at the beginning of the Hijri year, from $1^{\text {st }}$ to $15^{\text {th }}$ day. On these dates the moon will rise, precisely on $14^{\text {th }}-15^{\text {th }}$ day which is in Sundanese called "caang bulan opat belas". On this day, the people in the past often carried out the ngabungbang. The purpose of the ceremony to be held at the beginning of the Hijri year is to appeal to Allah that our hearts will be like caang bulan opat welas. "The point is to be saved the

The Sultanate of Yogyakarta (An Arbor: UMI, 1988) dan by Clifford Geertz, Santri, Priyayi, Abangan in Masyarakat Jawa, (Jakarta: Pustaka Jaya, 1981).

${ }^{7}$ Clifford Geertz, The Interpretation of Culture, (London: Sage Publication, 1970), p. 65.

${ }^{8}$ Ali, As'ad Said, “Bukan?-nya Seorang Gus Dur”, in Kata Pengantar Gus Dur Bertutur, Jakarta: Harian Proaksi, 2005. p. 10.

${ }^{9}$ Interview with Abah Ukat in January 2016. 
next world," said Abah Ukat. ${ }^{10}$

Implementation of the Seren Taun Guru Bumi in the cultural village of Sindang Barang has undergone several changes, in particular adjustments to Islam as the religion of the people there. For example in it is carried out in the month of Muharram, where cow slaughtering is performed in accordance with Islamic teachings and the meat is distributed to orphans and the poor. Prayer recited by a cleric is also currently using Islamic law.

Harmony here is understood in terms of the harmony between Islam and Sundanese culture. This means that the dialog between Islam and Sundanese culture did not separate them, the opposite in fact happened where it appears the Sundanese culture is rich with Islamic influences. Harmonization between Islam and Sundanese culture has been going on since Islam came to this region in peace. So there is no serious conflict between Islam and Sundanese culture. Even the term common among Sundanese people is Sunda teh Islam, Islam teh Sunda (Sunda is Islam and Islam is Sunda). ${ }^{11}$ This occurs because the two have the same guidelines, especially in terms of ethics and everyday behavior. Research on the ritual of Seren Taun Guru Bumi has been carried out several times, especially by students at the Faculty of Humanities, University of Indonesia. However, none of the research talked about acculturation or harmony that constitutes the elements of the ritual today, i.e. the theory of acculturation between Islam and Sundanese culture. The research focused more on the discretion of Sundanese culture and customs, despite the fact that this ritual is rich with the Islamic values which have been merged into the Sundanese culture.

The ritual of Seren Taun Guru Bumi is the harmony between Sundanese and Islamic culture that comes from the Middle East with arid desert sands combined with the culture of an agrarian society in the tropics. According to the analysis by Bambang Pranowo, this is a natural thing because theoretically a tradition works by creating something that is passed down from generation to generation, and its form still exists today. ${ }^{12}$

From this concept, the Seren Taun ritual can be understood in Tibis anthropological paradigm as a process of acculturation, assimilation, diffusion, and adaptation. Islam is understood as a collection with variations of interpretation in the context of the locality Seren Taun. Islam adapted and interacted with culture, so that in the concept of Habsbawn as quoted by

\footnotetext{
${ }^{10}$ Interview with Abah Ukat at the cultural village of Sindangbarang.

${ }^{11}$ Misno, Sunda teh Islam, Bogor: STAI Al-Hidayah Press, 2015, p. 76.

${ }_{12}$ Bambang Pranowo, "Runtuhnya Atkhotomi Santri-Abangan", in Jurnal Ulumidatn,
} No. 02, Th. IV, 2001. 
Pranowo, Seren Taun tradition necessitates two concepts of culture, i.e. the process of inheritance and construction. ${ }^{13}$

In line with the previous analysis, Ignaz Kleden's concept about cultural change can help to see how far the process of inheritance or conservation, and construction of the Seren Taun tradition, how it works and finds its context. Kleden provided five concepts, namely (1) at the level of the value system is from the integration, disintegration to reintegration; (2) at the level of cognitive system is through orientation to disorientation to reorientation; (3) at the institutional system, the change is from organization to disorganization to reorganization; (4) at the level of interaction is from socialization, dissocialization to resocialization; and (5) at the level of behavior, the process is from acceptance of behavior, refusal of behavior and acceptance of new behavior. ${ }^{14}$

Some changes and cultural shifts in the Seren Taun tradition in accordance with the concept of Kleden which stands out is the change in cognitive systems that religious knowledge was once filled with local beliefs has changed to more Islamic.

Islam's interaction with Sundanese culture in the tradition of Seren Taun as analyzed with the concepts suggested by Bassam Tibi, Pranowo and Habsbawn, Nur Syam, ${ }^{15}$ found a relevance with other anthropologists who emphasize the Islamic acculturation in the local culture, i.e. Mark R. Woordward, ${ }^{16}$ Muhaimin ${ }^{17}$, John Ryan Bartholomew ${ }^{18}$.

In contrast to the analysis of the theorists of acculturation of Islam and local culture, Islamic syncretism theory can be used to look closely at the tradition of Seren Taun in Sindang Barang. As advocates like Clifford Geertz ${ }^{19}$, Neils Mulder $^{20}$, and Erni Budiwanti ${ }^{21}$ who examined Islam Wetu Telu, could give birth to assumption that the Seren Taun ritual is a description of syncretism

\footnotetext{
${ }^{13}$ Bambang Pranowo, p. 9.

${ }^{14}$ Ignaz Kleden, Sikap Ilmiah terhadap Kebudayaan (Jakarta: Grameata, 1987), p. 169170.

${ }^{15}$ Nur Syam, Islam Pesisir (Yogyakarta: LKiS, 2005).

${ }^{16}$ Mark R. Woodward, Islam Jawa Kesalehan Normatif Versus Kebatinan (Yogyakarta: LKiS, 2006).

${ }^{17}$ Muhaimin AG, Islam in Bingkai Budaya Lokal Potret dari Cirebon, (Jakarta: Logor, 2001)

${ }^{18}$ John Ryan Bartholomew, Alif Lam Mim: Kearifan Masyarakat Sasak, (Yogyakarta: Tiara Wacana, 2001).

${ }^{19}$ Clifford Geertz, Santri, Priyayi, Abangan in Masyarakat Jawa, (Jakarta: Pustaka Jaya, 1981).

${ }^{20}$ Neils Mulder, Agama, Hidup Sehari-hari dan Perubahan Budaya, (Jakarta: Grameata Pustaka Utama, 1999).

${ }^{21}$ Erni Buatwanti, Islam Sasak, (Yogyakarta: LKiS, 2000)
} 
between Islam and local belief in Sindangbarang. In other words, there is a process of integration between two or more cultures (Islam, Hindu, Buddhism, and Animism) in the Seren Taun ritual.

Mulder's concept of syncretism in the Seren Taun ritual provides two basic concepts, i.e. (1) the culture can be understood as a cultural arena that facilitates the existence of some elements of culture that serve as a shaper; and (2) because it serves as a cultural arena, it could give birth to the implication in form of struggle for cultural contestation..$^{22}$ With reference to the concept of Mulder and theoretical implications, as far as the author observed, the preservation of Seren Taun ritual until now shows no cultural resistance from the local community. Instead, the two rituals contribute sociological form of consolidation of public functions that yearn for yearn for harmony. Indigenous or local tradition that grows among the people of Sindangbarang received guidance from the teachings of Muslim traditionalists.

This research used an ethnographical method with a phenomenological approach. Data collection used in this research was the method field research with an anthropological approach, and the analysis used methods of observation, interviews and documentation. Observations were carried out by following the process Seren Taun Guru Bumi ritual in the cultural village of Sindang Barang, Bogor. Observations were conducted on December 18 to January 24, 2016, from Monday through the peak of the ritual which was on Sunday.

In-depth interviews were conducted with key figures in this ritual, especially the indigenous elders in Kampung Sindang Barang, Bogor. Snowball technique was used, by looking for an informant who led to others who know about this ritual. Meanwhile the documentation was held at the Faculty of Humanities of the University of Indonesia to review the documents, books, scientific reports and resources relevant to this study.

\section{IMPLEMENTATION OF THE SEREN TAUN GURU BUMI IN THE CULTURAL VILLAGE OF SINDANG BARANG, BOGOR, WEST JAVA PROVINCE, INDONESIA}

The Cultural Village of Singdang Barang is located in the Village of Pasir Eurih, Tamansari Subdistrict, Bogor Regency, West Java Province. Located only 5 kilometers away from the city of Bogor or 60 kilometers from the city of Jakarta. The village is located at an altitude of 350-500 meters above sea level, consisting of 14 wards and 54 neighborhood associations with a total

${ }^{22}$ Neils Mulder, Agama, Hidup Sehari-hari dan Perubahan Budaya, (Jakarta: Grameata Pustaka Utama, 1999), p. 70. 
population of 1,200. Most of the inhabitants are sandal and shoe makers, and farmers. ${ }^{23}$

The history of Singdang Barang region has been known and recorded in the Chronicle of Pakuan / Pajajaran as one of the important areas of the Sunda and Pajajaran Kingdoms. This is because Sindangbarang housed one of the royal palaces where one of Prabu Siliwangi's wives named Dewi Mayang Kentring Manik Sunda lived, while the ruler of Sindangbarang at the time was Surabima Panjiwirajaya or Amuk Murugul. Even the son of Prabu Siliwangi and Kentring Manik Mayang Sunda named Guru Gantangan was born and raised in Sindangbarang. Until today there are archaeological remains i.e. the park of Sri Bagenda in Sindangbarang, with a pond with a length of $15 \mathrm{x} 45$ meters, and 33 spots of Punden Berundak..$^{24}$

The people here are actively involved in the Seren Taun Ceremony which can be seen from their enthusiastic participation in the ritual. In Sindangbarang village, there are eight kinds of Sundanese arts that have been revived and preserved by its inhabitants. Here, there are also archaeological sites of Pajajaran royal heritage in the form of terraces. In Sindangbarang, the traditional ceremony of Seren Taun Guru Bumi is held every year as an expression of gratitude of the community to God Almighty, and for the crop yields obtained this year and to hope for better harvest.

To preserve the traditional arts in the cultural village, gamelan dance training for young people is held free of charge. Youngsters who have advanced in their respective arts will be involved in performances to welcome guests which will contribute to their income. To preserve the archaeological sites, the cultural village collaborates with the FIB UI to conduct research, documentation and organizing seminars on the Pajajaran royal heritage sites. The folklores about Sindangbarang have been recorded by those from the FIB UI. Currently, adat houses and traditions in the cultural village of Sindangbarang have also been reconstructed and revived.

Revival of culture and adat houses is in fact necessary in order not to lose the Sunda identity. Staying with the kokolot will be a unique experience in this village because guests will feel the atmosphere of everyday village life. Here, guests will stay with the kokolot and artists who actually live in the village culture. Guests will also see women pounding rice in saung lisung, cooking with firewood and hawu (Sundanese traditional stove), watching farmers

\footnotetext{
${ }^{23}$ Direct observation on 17 January 2016.

${ }^{24}$ Agus Aris Munandar, Mengenal Situs-situs Kepurbakalaan Megalitik di Wilayah Sindang Barang Bogor, Paper presented at a discussion on Seren Taun held by Simpay (Paguyuban Guar Sunda) and the Center for Development of Arts and Culture of the Faculty of Humanities of the University of Indonesia.
} 
doing farming activities, and learning arts.

The attributes that accompany the Ceremony of Seren Taun Guru Bumi in Sindangbarang village, as mentioned above consisting of eight kinds of art, will enliven the ceremony. These arts among others are calung, martial arts, dance, gamelan, reog, etc.

Rice which serves as an important part of the seren taun ceremony is complemented by fruits and vegetables that are all derived from local yields. Music, dance, and other attractions add to the attractions of the annual event. The event of Seren Taun is usually filled with a variety of other forms of entertainment. Community leaders, elders, community members, local and foreign tourists join the festivities in the village.

Seren Taun is a Sundanese community ritual performed every year, taking place solemnly and lively in the village of Pasir Eurih, Sindangbarang, Bogor, West Java. The traditional ceremony as a celebration of this agrarian society is enlivened by thousands from Bogor and the surrounding communities, even from several areas in West Java and abroad. “

The annual event is attended by community and traditional leaders of Bogor Sundanese with activities being centered in the cultural village of Sindangbarang, Pasir Eurih Village, Tamansari Sub-district, Bogor Regency. Those who want to see cultural or artistic activities of the Sundanese are welcome, because the event is open to the public and free of charge," said the pupuhu (traditional leader) of the cultural village of Sindangbarang, A. Mikami Sumawidjaya. ${ }^{25}$

The indigenous or Sundanese arts to be shown in Seren Taun among others are ritual of circumcision of a child, starting from sawer sudat, parade around the village, and sebret kasep. The event is interesting because there are 30 boys that will be circumcised in accordance with the Sundanese tradition and filled with art performances during the three phases of mass circumcision. "Seren Taun is held with the purpose of expressing gratitude and joy to God for all the sustenance received by the community over the past year and pray for abundant harvests and avoid disasters in the years to come," said Sumawijaya.

In addition to performances of Sundanese arts such as jaipong dance, kendang rempak dance, pencak, angklung gubrak, and reog, there is also a puppet show. In addition the event is also filled with the Munday ritual (parading and slaughtering cows for alms and side dishes), fishing in the river, and cake giveaway.

${ }^{25}$ Interview with Ahmad Maki Sumawijaya during the event of Seren taun Guru Bumi 18 January 2016. 
The peak of Seren Taun is helaran dongdang which is a procession of people who carry dongdang (ornate container) containing crops and other community economic product. Following the procession, various Sundanese arts are displayed. The highlight of this event was held on January 24, 2016 on Sunday from 08.00 until late afternoon. A series of rituals are performed in front of the village elder in Sindangbarang Cultural Village complex, Bogor.

The ritual of Seren Taun Guru Bumi is the ancestral heritage of the Pasundan community, which according to the elders, it must be preserved despite the swift the new culture as well as that of the Western. So whatever the consequences are, the ritual has to be implemented. Those who obey and those who disobey or pros and cons continue to be the talk of the elders of the pasundan culture.

The traditional festivities of Seren Taun Guru Bumi in Sindanngbarang Bogor this year began to be held on Monday, from January 18 through January 24, 2016. It began with a visit by the traditional leaders of Bogor Sundanese in Sindangbarang to the tombs of the ancestors on Gunung Salak. This ritual was carried out at night where people carried equipment such as parupuyan (censer), perfume, flowers of seven types, coffee, milk, tea and cigarettes. A kokolot served as a leader in this tomb visit.

The procession began with a kokolot (an elder person) who knelt in front of the tomb of Eyang Cakra Bumi on Gunung Salak. After reading some mantras and prayers then some incense was burnt, and the atmosphere was quiet with the scent of incense being burnt and the smoke rising into the sky. According to Aman Kang, smoke is a medium to communicate with the spirits of the ancestors who have died. ${ }^{26}$ After incantations and prayers were completed, then all members of the group returned to their respective homes.

The next stage of the ritual of Seren Taun Guru Bumi is to take water (which is considered holy) by the public at Sindang Barang, Bogor. The water taken from sacred wells Jalatunda is believed to have an effect for those who drink and take a bath there. The water is then brought to the kokolot's home accompanied by the community and other indigenous leaders. Then the procession continued and accompanied by Sundanese cultural arts or arts performed by the surrounding communities. A group of people were carrying rice, vegetables, fruits, and livestock.

The celebration of this ritual is when people bring dongdang (a type of stretcher) filled with fruits, vegetables and other crops. Each RT (neighborhood association) and RW (ward) in Pasir Eurih brought dongdang which was carried by four men. Some women also accompanied the group

${ }^{26}$ Interview with Kang Aman at the tomb visit as part of Seren Taun Guru Bumi in January 2016. 
with a complete angklung in Sundanese traditional clothes. In the ritual of Seren Taun Guru Bumi, people usually carry two bunches of rice paddy to be delivered to the village elder to be stored in the barn (leuit). According to the village elders, this is a time of preparation by the community if anyone needs it. At that moment, the leuit will be opened to provide food to those in need.

The culmination of the Seren Taun Guru Bumi ritual is storing rice into the leuit (typical Sundanese rice barn), which is the final rite in a series of processions. Storing rice in the leuit is done in a solemn manner accompanied by Sunda songs as "entertainment" for Nyi Pohaci who is going to "sleep". Finally, a religious leader will close the ritual with a prayer for the safety of the whole community in Singdang Barang. ${ }^{27}$

In some areas in Tatar Sunda, in the event, people usually bury a cow head into the ground. However, this tradition is no longer practiced in the cultural village of Sindang Barang. The cow that has been slaughtered is then distributed among the orphans, the poor and guests who come to the event. Similarly, a ritual that may contain polytheistic practices is not carried out as part of their Islamic faith.

After the ritual is completed, everyone will be entertained with a variety of traditional arts. Even the arts stages are provided, usually more than one or even five stages, each being filled by various kinds of music and arts, even the original art of the Chinese lion dance. In addition to arts, temporary markets also help enliven the event. To entertain visitors, the event may take more than one day, and maybe up to three days or a week. This ritual, in addition to a visit by the community itself, it is also attended by visitors from outside the village such as Jakarta and even foreign tourists from Denmark.

Seren Taun Guru Bumi has become the annual folk festivity for the community in Sindangbarang in particular and Bogor in general. They are comforted by this event so that in the future it must be preserved. The participation of the local government is very important for the sustainability since it requires a lot of fund. ${ }^{28}$

\section{HARMONY BETWEEN ISLAM AND PASUNDAN CULTURE}

The harmony between Islam and Sundanese culture in the Seren Taun Guru Bumi ritual in Sindangbarang village is an acculturation between the two. The Islamic form of harmony is when introducing the values of gratitude to the

${ }^{27}$ The event of the Seren Taun Guru Bumi ritual at the cultural village of Sindangbarang is not much different to that carried out in other indigenous villages, for example in South Sukabumi Cisungsang.

${ }^{28}$ Interview with Ahmad Maki Sumawijaya in January 2016. 
community, especially the ritual of Seren Taun Guru Bumi, of course, it should be an expression of gratitude not only for harvest of rice alone, but whenever possible. However, in traditional societies, it is not easy to remove the belief in the gods. Therefore, this ritual serves as a prelude to teach gratitude to the Creator.

The form of harmony between Islam and the pasundan community especially in the Seren Taun ritual is advised to bring other crops in addition to rice such as grains, fruits, vegetables, and livestock animals, usually for cattle, it is already in the form of food or fast food. For fast food, such as vegetables, rice and side dishes which in the past was buried into the earth or dumped into the sea, is now used again for food to be cooked and eaten together.

The harmony taught by Islam is for the Sundanese people who still perform the rituals Seren Taun Guru Bumi, sooner or later to understand the nature of real gratitude. When we refer to the discussion of Sundanese culture, in fact, with their ritual of Seren Taun Guru Bumi, the people around the village no matter the ethnicity or religion, can interact without any social distinction.

As a result of acculturation, the Seren Taun Guru Bumi is a culture that has two distinct elements, i.e. the Sundanese culture and the overall culture of Islam. The Sundanese culture as the origin of this ritual in the past was filled with pagan beliefs, i.e. exaltation of Nyi Pohaci (Dewi Sri) and giving offerings to her. Islam came and gave color to this ritual in the form gratitude to and glorification of Allah the Most High. The tomb visit is carried out using the procedure of pilgrimage in Islam, so is the belief in the water of the Jalatunda well that comes from Allah. Cow slaughtering is conducted with Islamic law and the meat distributed to orphans and the poor. No cow head is buried or dumped into the sea. Mass circumcision, despite using the procedure of Sundanese culture, it is definitely part of the Islamic law.

\section{CONCLUSION}

Seren Taun Guru Bumi is the result of acculturation between Sundanese culture and Islam. The practice of this ritual in the cultural village of Sindangbarang is an effort to revive the Sundanese tradition that has long been gone. This ritual in the past was a form of exaltation of Nyi Pohaci (Dewi Sri) which is believed to be the goddess of rice in Tatar Sunda (West Java). Currently the implementation has been colored with Islamic elements, not only symbolically but also in the belief.

The Islamic elements in the ritual of Seren Taun Guru Bumi can be seen in this ritual as a form of gratitude to Allah the Most High who has provided us with sustenance throughout the year. Furthermore, in the procession, it is also 
filled Islamic cultures, for example tomb visit which is done in accordance with the Islamic procedures, cow slaughtering in which the meat is intended for orphans and the poor and mass circumcision performed in a series of rituals.

The Sundanese culture is still visible in the outfit worn, the use of incense and various Sundanese arts performed. Similarly, the Sundanese symbols also characterize the course of the ritual from beginning to end which include the location of the ritual which is held in front of the home of the village elder located in the cultural village of Sindangbarang Bogor.

As a local ritual, the community and the government should preserve it. As long as it does not have conflict with the Islamic values, then it is very likely to be continued. If there is part of the ritual that is contrary to Islamic teachings, it is the responsibility of the scholars to straighten it. This ritual is expected to be an asset for Bogor tourist attractions. Hopefully, it will increase the number of local and foreign tourists to come to the village. There is no doubt that the role of the local government of Bogor is crucial in preserving the Seren Taun Guru Bumi ceremony in the cultural village of Sindangbarang, Bogor.

\section{REFERENCES}

Abdurrahman Misno, Reception Through Selection Modification: Antropologi Hukum Islam di Indonesia, Yogyakarta: Deepublih, 2016

Dhavamony, Mariasusai, Fenomenologi Agama, Terj. A. Sudiarja dkk, Yogyakarta, Kanisius, 1995.

Ekajati, Edi S., Masyarakat Sunda dan Kebudayaannya, Jakarta: Giri Pasaka, 1984.

Gazalba, Sidi, Pengantar Kebudayaan sebagai Ilmu, Jakarta: Antara, 1968.

Gellner, David N., "Pendekatan Antropologis" dalam Peter Connolly (ed.), Aneka Pendekatan Studi Agama, Yogyakarta: LKiS, 2002.

Iskandar, Yosep, Sejarah Jawa Barat (Yuganing Rajakawasa), Bandung: Geger Sunter, 1997.

Johan Iskandar dan Budiawati S. Iskandar, Agroekosistem Orang Sunda, Bandung: Kiblat Utama, 2011,

Lubis, Nina H., Kehidupan Kaum Menak Priangan 1800-1942, Bandung: Pusat Informasi Kebudayaan Sunda, 1998.

Madjid, Nurcholish, Islam Doktrin dan Peradaban Sebuah Telaah Kritis tentang Masalah Keimanan, Kemanusiaan dan Kemodernan, Jakarta: Paramadina, 2000. 
Cliford Geertz, Islam Observed, Chicago: The University of Chicago Press, 1975.

Nawawi, Hadari, Metode Penelitian Bidang Sosial, Yogyakarta: UGM Press, 1995.

Razak, Abdul, Teologi Aliran Kebatinan Sunda; Kajian Antropologi Agama tentang Aliran Kebatinan Perjalanan, Bandung: Kiblat, 2005.

Soepanto, "Asal Mula Padi (Tjerita Rakjat dari Pasundan)" dalam Kumpulan Tjerita Rakjat Indonesia, Bandung: Urusan Adat-Istiadat dan Tjerita Rakjat Dep.P.D dan K Djawatan Kebudayaan, 1963.

Anis Jatisunda, Upacara Seren taun Guru Bumi di the cultural village of Sindang Barang Kabupaten Bogor. Makalah, Tt.

Rahmat Subagya, Agama Asli Indonesia, Jakarta: Yayasan Cipta Loka Caraka. 1981.

Yuyus Suherman, Sejarah Perintisan Penyebaran Islam di Tatar Sunda, Bandung: Penerbit Pustaka, 1995.

Danasasmita, Saleh. Sejarah Bogor, Bogor: Dinas Kebudayaan Pariwisata dan Ekonomi Kreatif Kota Bogor, 2012.

Team Penyusun dan Perumus, Proceedings Seminar Nasional Sastra dan Sejarah Pakuan Pajajaran, Bogor: Universitas Pakuan dan Yayasan Pembangunan Jawa Barat, 1993. 